Journal of Engineering and Applied Sciences 15 (6): 1298-1305, 2020

ISSN: 1816-949X

(C) Medwell Journals, 2020

\title{
Reconstruction of Prehistoric Environment and Human Adaptation in Cave Sitesat Belae Village, Pangkep Regency, South Sulawesi, Indonesia
}

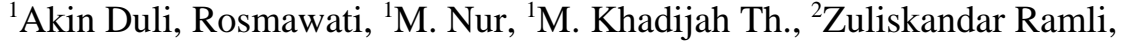 \\ ${ }^{2}$ Nurul Noorain Ahkemal Ismail and ${ }^{2}$ Nur Sarahah Mohd Supian \\ ${ }^{1}$ Department of Archaeology, Faculty of Cultural Sciences, Hasanuddin University, \\ Makassar, Indonesia \\ ${ }^{2}$ Laboratory of Archaeology and Archeometry, \\ Institute of the Malay World and Civilisation (ATMA), Universiti Kebangsaan Malaysia, \\ Bangi, Malaysia
}

\begin{abstract}
The life of prehistoric people was highly depending on their surrounding physical environment. They have produced material culture (artefacts) in a very simple form and function which could help them to meet the needs of their everyday life. Adaptation to environment is a solution in their modest culture. Reconstruction of physical environment, therefore is essential for prehistoric archaeological research. The method used in this study was survey on prehistoric sites at Belae-Pangkep, through observations on environmental and adaptation variables of prehistoric people in the past. The results show that the environment has karst characteristic which located at a transition area from freshwater to saltwater between coastal and land area. Prehistoric people lived with adaptation patterns to these different environmental phenomena.
\end{abstract}

$\underline{\text { Key words: Belae Pangkep, Toala, Maros point, cave paintings, prehistoric people, environmental phenomena }}$

\section{INTRODUCTION}

Current archaeological studies have rapidly developed. The developments were not only occurred in the formulation of models, concepts and theories but also in its methodology. Methodological development in archaeological research is highly influenced by other sciences either social sciences or exact sciences. For instance, the reconstruction of social, economic, political and religious life was greatly supported by social sciences; whereas, reconstruction of space and time was contributed by exact science. Thus, archaeology is a multidimensional science.

There are three main aspects of past reconstruction which become the aim of archaeology: formal, spatial and temporal aspects. Formal aspect is related to either visible or hidden past cultural forms through artefact analysis; spatial aspect is related to "area" in which a culture adapted and developed in particular period; temporal aspect is related to questions on the emergence, development and extinction of a specific culture. It seems that spatial and temporal aspects in this context are inseparable.

Discussion about spatial aspect in the interpretation of past cultural activities is equal with the reconstruction of environment in which a culture has occurred. The reconstruction of archaeological environment is essential in conclusion about human's ways of life in the past, as this process of reconstruction can provide some information.
Archaeologist's concern on environment, other than to find out its contextual relation to human culture is to study several factors which results in changes of artefact forms or natural data transformation. This lead to ideas which has specific emphasize on archaeology later known as environmental archaeology. In principle, this study suggests that development of human culture is closely related to its surrounding environment. Environmental archaeology discusses about human culture in which its environment is considered as a variable introduced into a cultural system framework.

This cultural domain, the influence of environmental factors on technology is described. Human culture begins when humanity lives in one place and carry out their daily activities by Ismail et al. (2018). However, any daily activity or any cultural heritage that they used or practiced was not recorded. Cultural heritage can be categorized into cultural and natural heritage. It consists of customs, practices, monuments, objects, group of buildings, artistic expression or archaeological sites with outstanding value of history, art, aesthetic, science, ethnological or anthropological by Roslan et al. (2017).

\section{MATERIALS AND METHODS}

This is an initial investigation which aimed to reconstruct the prehistoric environment and the patterns of human adaptation at prehistoric caves at Belae. Method used in this research is survey on the environment surrounding prehistoric caves through observation and the

Corresponding Author: Akin Duli, Department of Archaeology, Faculty of Cultural Sciences, Hasanuddin University, Makassar, Indonesia, (0411) 587223590159 
inventory on physical environment and archaeological data. In addition of data obtained from survey, data from previous study were also used. Those data were analysed and the results became a basis for environmental reconstruction and to interpret prehistoric people's adaptation pattern in the past.

Environmental and archaeological data: General view on prehistoric caves area at Belae village, Pangkep. The area subjected to this discussion is an environment with karst topography in which prehistoric caves were located. Topographically, this region is a highland which constituted by a series of karst (limestone) mountain and land. To reach this region, we could use motorcycle or car through twisting road alongside mountains. To the left and right of the road there are rice fields and local settlements. The width of this region is about $12 \mathrm{~km}^{2}$.

Geographical and Astronomical Administrative Positions of Prehistoric Caves at Belae village: Administratively, the region of Belae prehistoric caves is located at Belae village, Minasa Tene sub-district, Pangkep regency (Pangkajene and islands), South Sulawesi province, Indonesia. Minasa Tene Sub-district boundaries are: Bungoro sub-district in the North; Balocci sub-district in the South; Pangkajene sub-district in the west and Bantimurung sub-district (part of Maros regency) in the East. The series of prehistoric caves at Belae village are located in a karst mountainous of Minasa Tene region which stretches in a West-East direction. Belae village is a region which has largest group of identified prehistoric caves compared with other regions in Pangkep which are Labbakkang (in Labbakkang sub-district), Sumpang Bita and Bulusipong (both at Balocci sub-district) and Garunggung (Bungoro sub-district). Karst structure in Minasa Tene is a part of karst system which stretches from Maros regency in the South to Barru regency in the North and known as West Mountain group in South Sulawesi mountain system.

Mostly, geography of Belae Village is lowland which extended toward Western coast. This condition suited for local people to make rice fields. To the East is a karst or limestone mountain which stretches from West to East and then bend Southward. In the slope of these mountains, sago, palm trees and other wild plants were growth. In rainy season, area besides the mountain are filled with water and become swamps.

By its climate, Belae is part of Pangkep regional climate system which are an inter-tropical convergence area and therefore, in the beginning of January this area has an average annual rainfall of more than $2000 \mathrm{~mm}$. Based on rainfall data obtained from Meteorological and Geophysical station, the average rainfall in this area is $3.397 \mathrm{~mm}$. Wet season occurred for 6 months and dry season for 3-4 months. Average annual temperature in
Pangkep which has elevation between 10-100 $\mathrm{m}$ above sea level is ranges between $22.6-27.5^{\circ} \mathrm{C}$ by Eriawati. Meanwhile, ranges of daily temperature is $25-33^{\circ}, 25^{\circ}$ occurred in the night at rainy season and $33^{\circ}$ in daytime at dry season. Astronomically, the region is located at $119^{\circ} 29^{\prime} 49^{\prime \prime}$ Eastern longitude and $4^{\circ} 47^{\prime} 40^{\prime}$ ' Southern latitude by Asmundar.

Geomorphology and geology: Overall, prehistoric caves sites in Pangkep which already identified today are 35 sites unit. Those caves were formed naturally and located either at the slopes or foot of limestone hills with varied elevation between 10-300 m above sea level. In general, conditions in this environment are limestone hills forests on its top and slope, swamps and rivers in front of cave which covered by palm trees and rice fields in the foreground.

Limestone caves were formed as a result of limestone dissolution which occurred very slowly in a long period and eventually formed the caves and shelters. Caves, however, could also form in any types of rocks along coastal area as a result of continuous rocks erosion which formed cavities near coast line. Thus, all caves in the area were formed by processes described above.

Pangkep regency is a part of Pangkep-Maros-Bone region which marked by two karst mountain ranges which stretches from North to South and a valley between them, known as Walannae valley, through which Walannae river flow. At Western slope and several places at Eastern slope of this mountain path there was karst topography indicating the presence of limestone. Karst bed rock is limestone type of eocenenummulite with flat and relatively pure thick layers on schist crystalline and volcanic genes cretaceous ophiolite by Balazt, Eriawati, Said. According to geological history of South Sulawesi, the formation of limestone hills was occurred in early Eocene to middle Miocene at ancient sea floor. Those hills were lifted up to the surface by tectonic activities in the form of ancient volcanic eruptions which took place from Late Miocene to Pliocene by Sunarto, Said.

Pangkep-Maros karst has lithological unit of volcanogenic igneous (basaltic), limestone and marble from Eocene to middle Miocene by Balazt in Eriawati, Said. Whereas, based on its lithostratigraphy, this area is divided into four rocks units: Alluvial unit which consists of clay, silt, sand, gravel, coastal deposits which contain shell remains, coral limestone and sea clay insertion which contains molluscs. Igneous unit, a unit of intrusion rocks which composed of basalt, diorite and trachyte. The results of igneous rocks are jasper, chert and meta-limestone. These types of rocks were formed in lower Miocene. Limestone unit which have been metamorphosed to meta-limestone, chert, manganese nodules, jasper and marble. This unit was from lower part of middle Eocene with depositional environment ranged 
from shallow neritic to the deep sea and lagoon. And finally, there is a sandstone unit which being inserted by coals insertion. This sandstone was formed in lower Eocene with depositional environment of swamps by Intan.

Rivers at Pangkep region are categorized into dendrite and rectangular rivers. Dendritic rivers have a formation and flow that resembles a tree with its branches which specifically occurred at plain landscapes with homogenous rocks. Rectangular rivers have angular branches and occurred at fault area by Whitten et al., Intan. The main rivers in Pangkep area is Pangkajene river and middle rank rivers include Pappanaungang, Jallo, Belae, Kalangkere', Lampe and Tallang rivers. Based on its forms and flows, these rivers categorized as episodic river with mature stadia by Intan.

In general, vegetation in this region could be classified into four types: vegetation which growth at karst mountain, lowland vegetation, swamp vegetation (freshwater) and coastal and swamp (saltwater) vegetation. Karst vegetation is characterized by banyan, merana, noni and ferns such as Adriatum sp., Drynaria sparsisora, Ligodium flexuosum and Pteris sp., whereas, lowland vegetation is characterized by shrubs with various plants by Eriawati.

Freshwater plants which covers freshwater swamp includes hidrillagrass or swamp algae (Hidrillaverticillata), floating ferns (Salviania sp.), water grass (Patomegenon), yellow velvetleaf (Limnocharisflava), kangkung (Ipomoea aquatic), sago (Metroxilonsagu), pandan (Pandanustectorius) and daffodil (Amaryllis sp.). Sea/brackish swamp vegetation alongside rivers which still affected by sea tidal includes Apiapi (Rhizophora mucronata), mangrove plants such as Avicennia officinalis, Achantusillicifolius, Xilocarpus sp., Heritiera littoralis, Baringtoniaasiatica, Lumnitzeralittorea and kandeka (Bruguiera conjugate). Plants types at brackish swamp are nipah (Nypafruticans), pandan (Pandanustectorius) and other several coastal plants by Eriawati (Fig. 1).

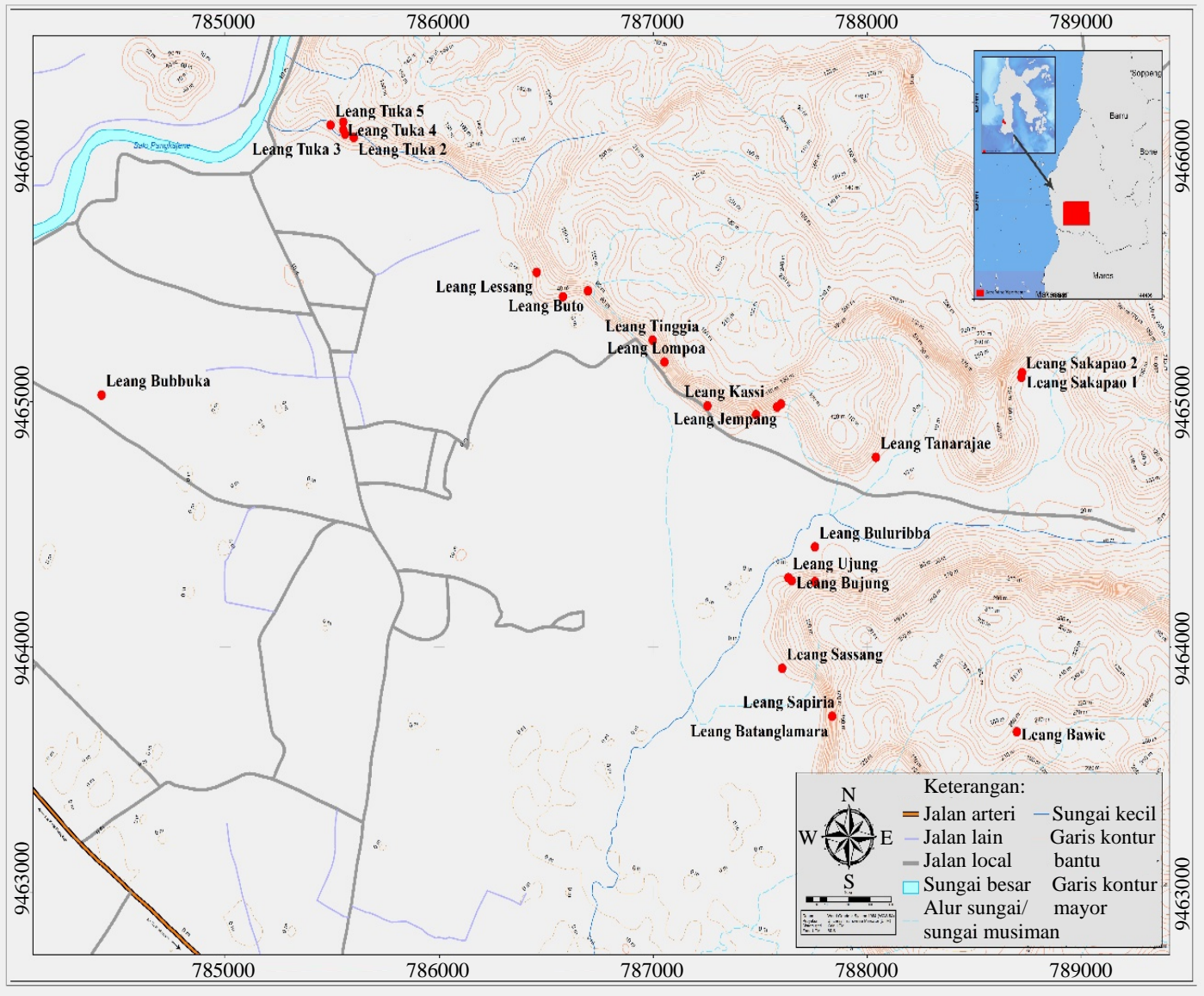

Fig. 1: Map of distribution of prehistoric sites in the Belae area, Pangkep 


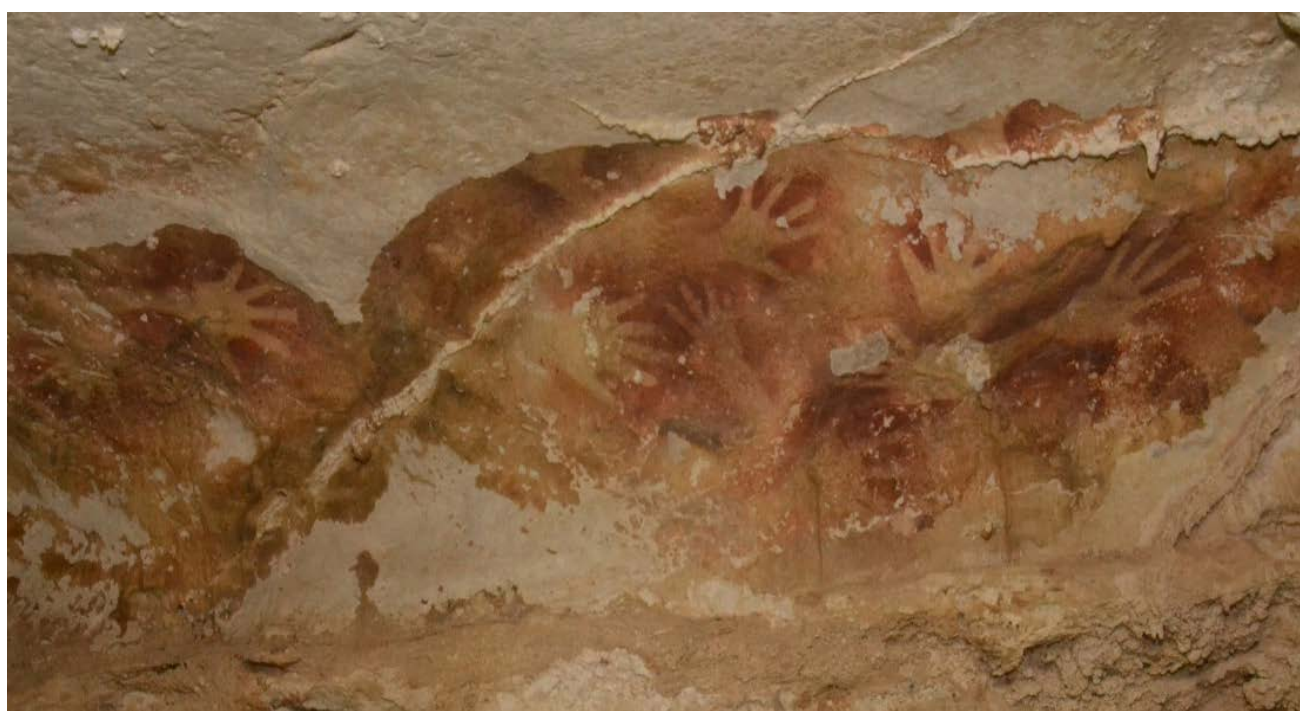

Fig. 2: Cave painting in Sakapao cave site at Belae

Variables of archaeological data at Belae village prehistoric caves: Belae caves site complex, as described above is a series part of Pangkep regional karst topographic unit. This topographic unit has irregular shape. Caves series was located at Northern side, surrounding a half circle of the cave sites complex. Overall, there are 25 prehistoric caves in this area which are Tukka, Lessang, Limbubuka, Caddia, Lambuto, Tinggia, Lompoa, Kassi, Kajuara, Pattennung, Jempang, Tanarajae, Sakapao, Bujung, Bayya, Buloribba, Cammingkana, Bujungbujung, Ujung, Sassang, Batanglamara, Sapiria, Lamperajang, Ulutedong and Saluka caves.

Accumulatively, archaeological finds from this area are cave paintings and flakes, blades, arrow head, core tools, chipped stones, spear head, pointed stone, pointed stone and tools made from mollusc shells.

Cave paintings were found at cave walls with various heights. Painting types includes hand stencil, fish, human, pig, boat, tortoise, geometrical and abstract painting. All these pictures were dominated by red color. Painting technique used are spray which result in negative pattern (for hand stencil) and smear (rub) for positive pattern (for human, fish, tortoise, geometrical and abstract paintings). Artefacts found in the caves are flakes, blades, pointed tools, bone tools, shells and others artefacts which found either on the surface or obtained from excavation. Beside artefact finds, food remains (kitchen middens) from animal such as boar (Sus celebensis), deer (Cervustimorensis), rats (Rattusrattus), Sulawesi weasel (Macrogalidiamuschenbroela) and jungle fowl (Gallus galvus). In addition, there are several types of shells from phylum mollusc and crustacean. Based on their ecotones, the consumed shells were classified into marine molluscs and mangrove molluscs. Marine molluscs include Truchyardiumangulatum and Fragumunedo, whereas mangrove molluscs include Teleskopiumtelescopiun, Telebralaiafalustfis, Ellobium aurisjudae, Sincerabrevicula, Chicoreous adustus, Polymesoda, Scylla senatacoaxans and Anadara antiguata, as well as several types of crabs by Suprapta (Fig. 2).

\section{RESULTS AND DISCUSSION}

Reconstruction of environment and prehistoric human adaptation pattern at belae village-Pangkep caves: Prehistoric era which characterized by hunter gatherer living was occurred, since, pleistocene to postPleistocene. The inhabitation of prehistoric caves at Belae village was occurred in post-Pleistocene in which the condition of living environment was not much different as it is today. People who live in this age prefer a cave that located on the higher ground and had a good lightning to brighten the surrounding area, traits by Afiq et al. The hunter gatherer living at this environment is evident from the tools which made from stones, bones and mollusc shells. A stabilizing natural condition which began in post-Pleistocene has allowed reductions on the threat of natural changes encountered by human and give them a greater chance to adapt and create by Ismail et al. (2018), Duli and Rosmawati (2018).

In Indonesia, the efforts to living precariously at natural caves were started in that era by Soejono and characterized Mesolithic living. Human adaptation on natural facilitation has marked a progress made by human in their interaction with environment. The advantage of cave living has provided a shelter from the threats of natural danger, enemy, wild animals, heat and rain. This 
condition allowed human who lived in caves, to focus their energy on others goals such as making living tools, hunting, planting crops and so on. It showed that the environment and culture of the people who had lived in the aforementioned cave and made it as a stopover and shelter based on archeological findings such as artifacts consisting of lithic tools, earthenware and ecofacts (such as snail shells and animal bones and cave paintings) by Shamimi et al. The differentiation on works was begun to distinct, as well as religious living. The evidence of caves living in Indonesia mainly found at Lawa cave near Sampung, Ponorogo, East Java, Prajekan and Tuban caves, also in East Java and prehistoric caves in Maros-Pangkep area in South Sulawesi. Utilization of the cave as a dwelling and burial activity, continues to age protohistory, for example in Enrekang by Duli (2013, 2014, 2015).

Besides living in caves, there were also human groups who lived at coastal area and rather depend on food sources from the sea. The evidence of this kind of living was shown at kjokkenmoddinger (kitchen midden) sites at Langsa and Tamiang, East Aceh and also in Eastern part of Sumatera island. Today, there were assumed two major human races lived in Indonesia, Australomelanesoid and mongoloid which emerged about 10.000 years ago. At the end of the Neolithic stage, the people had mastered the skills of using and building boats. The development of this transport technology had enabled the establishment of are lationship with distant societies by Supian et al. (2018).

The dominant culture in that era, besides continued food hunting life, the use of pottery with simple technology was also introduced in some place. The development and advancement of the Neolithic society can also be identified through the method of pottery production. They used sunlight to dry the pottery that had been formed. Even though at the time they knew how to use fire but they were not yet able to create a systematic burning stove by Supian et al. (2018). Stone tools technology was advanced and finer although its function characteristic shows sustain ability from previous era. The importance thing in this era, however is the discovery of religious life evidence which represented by wall painting with various meanings and functions.

A series of research on prehistoric caves at South Sulawesi has provided some important terminology on flake-blade tradition in Indonesia. Experts who shed light on this area were Fritz and Paul Sarasin. Both of them have conducted excavations at Cakondo, Uleleba and Balisao caves in which they have found flake tools, along with jagged arrow heads, bone tools and fragments of human bones. Sarasin suggested that Toala peoples who lived in that area is a descent of Wedda people from Ceylon and they show physical differences compared to Bugis people. The next investigation, conducted by
W.A. Mijsberg, showed a contrast results to Sarasin, suggesting that there were no physical differences between Bugis and Toala peoples by Soejono. In 1933, van Stein Callenfels, along with H.D. Noone and A.A. Cense, conducted an investigation at Tomatoa Kacicang cave in which they have found flake-blade tools, jagged arrow head, piercer from jagged bones, bone spatula which similar to Sampung type and bone tools which pointed in both end (known as muduk points) (Fig. 3).

Van Heekeren, in excavation at Leang Karrasa (Maros) have found flake-blade tools, scrapper, knife, piercer and jagged stone tools, as well as potteries. Later, Heekeren continued his investigation at Panganreang Tudea cave (Pangkajene) and Saripa cave. The finds obtained from those sites were flake-blade tools, shells tools and little jagged arrow head. This investigation was continued in 1950 at Leang Pettae near Leang-leang (Maros). Although, unfinished, this investigation has managed to identify animal bones, hematite, knife and auger.

Other finds were obtained from Ara cave (Bulukumba), a place discovered by Cense in 1933. In this place, the formations and levitations of coastlines has occurred repeatedly and allegedly there were seven coast steps. When Heekeren investigated the place, he found bone tools such as spatula, bone points, spiral decorative glass with light blue color, jagged stone tools and bones spatulas.

In an excavation conducted by W.J.A. Willems and F.D. McCarthy at Panisi Tabbuttu (Bone), jagged stone tools were also found, along with bone tools, blades, shells scrapper and bone spatula. They also excavated Codong cave near Citta (Soppeng) and found scrappers made from shells, jagged arrow heads, pottery and metal artefacts.

The next was excavation conducted by van Stein Callenfelsat Batu Ejaya cave (Bantaeng) which found decorated pottery, quadrangular pickaxe, Dutch coins, bronze bracelet, bone tools, jagged stone tools, millstone and bracelet. In his second excavation at Panganreang Tudea, he found jagged tools, pottery, bronze hooks, stone beads, bone tools and piercer made from shells.

Based on those results, Heekeren has categorized three cultural layers of Toala, from lower to upper as follows: Toala I or upper Toala which characterized by winged and jagged arrow head, muduk points, shells scrapper and pottery; Toala II or upper Toala which characterized by blades, arrow head with circular base and microliths; Toala III or lower Toala which characterized by big, coarse flakes and blades includes conclave edged flakes and handled blades by Soejono. "Toala Cultures" terminology in referring to people who lived in South 


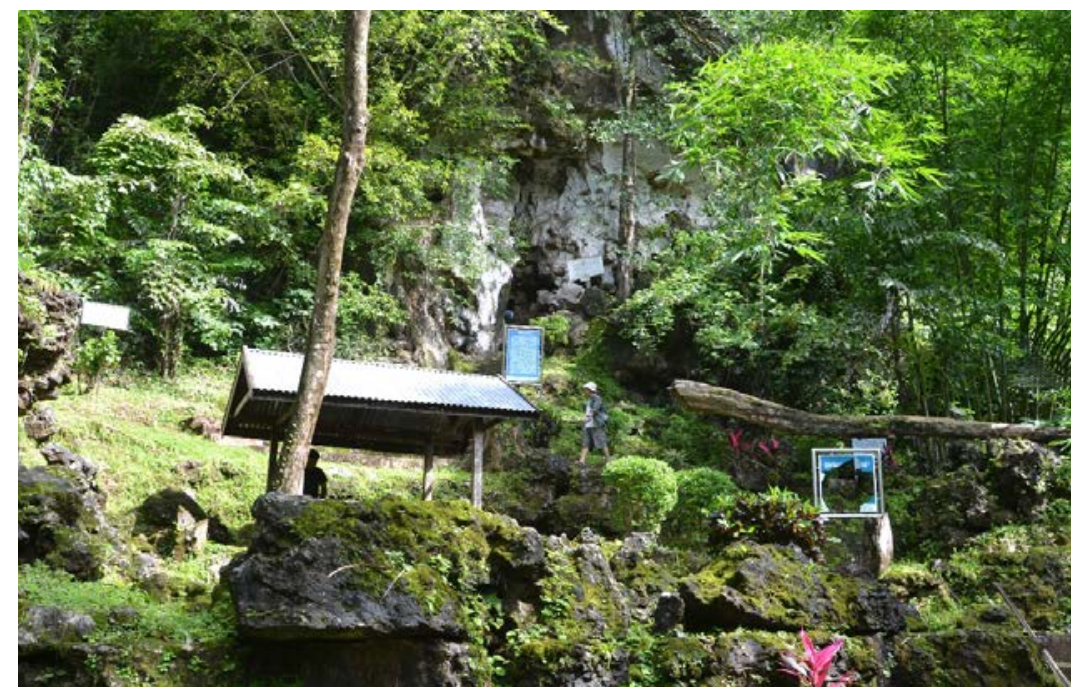

Fig. 3: Surface condition of Leang Tinggia cave at Belae village

Sulawesi prehistoric caves, coined by Heekeren was still adopted until today, albeit several studies were already reconsidered the terminology.

Prehistoric caves in South Sulawesi, particularly those which had been studied, provide several archaeological and non-archaeological evidences related to Mesolithic life. The life at Mesolithic time, as termed by the experts was the next step of Palaeolithic life which in South Sulawesi was shown through cave lives. In accord to formal dating, the caves were occupied at $3790 \pm 230$ S.M. and $5520 \pm 650$ S.M. by Soejono. Meanwhile, in 1973 and 1975, I.C. Glover conducted a research at Ulu Leang and Leang Burung caves at Maros. He found flakes, bone points, potsherds, animal remains and rice chaff with absolute date between 10,500-3,500 BP through C14 dating by Glover, (1976). Last research gave a date of 39,000 years for cave painting at Maros area Aubert et al. (2014). Time termination which assigned between 40,000-3,500 years ago for caves occupations in Maros and Pangkep was referred as a base for reconstruction of environment and human adaptation in that era.

Results of several studies indicate that environmental situation at the time of Belae prehistoric caves occupation was a combination of terrestrial and aquatic environments with mangrove acted as a transition environment between them. Based on those results, mangrove environment at that time was located about a kilometer away from karst mountains which proved by pollen analysis. At present, the mangrove vegetation was regressed about $10 \mathrm{~km}$ from coastline. When the tide is up, sea level was moved closer to the karst mountain and when the tide is receding the coastline was regressed again. This cycle was continued until re-elevation has occurred which caused the sea level regressed to location as it presents. The evidence of this fluctuation is marine molluscs and mangroves which deposited as kjokkenmoddingerat cave mouths.

The reconstruction of life related to subsistence adaptation patterns by peoples who occupied Belae village prehistoric caves, particularly about the hunt for terrestrial, aquatic and mangrove, could be performed through functional analysis on stone tools and an analysis on food remains which sourced from terrestrial, aquatic and mangrove animals which found in kitchen midden remains. From the results of researches conducted by the office of Preservation on Historical and Archaeological Heritage province of South and Southeast Sulawesi, National Research Centre of Archaeology, National Coordinator for survey and mapping agency and several independent researches which have found Mesolithic stone tools at Pangkep area, the tools could be classified into several types: massive tools, core tools, flakes, blades, scrapers, points and chipped stone. In addition, tools made from shells were also found and categorized as scraper. From functional analysis based on the description of sharpened forms and position as well as wear and usage marks, it was found that those stone and shells tools probably used as tools for picking, scrapping, chopping and pricking.

As for analysis on food remains, the results show that those remains were came from both vertebrate and invertebrate. The invertebrate includes phylum mollusc and crustacean and vertebrate includes mammalian, reptilian and avis. Consumed molluscs, based on their ecotones were categorized into marine and mangrove molluscs. Marine molluscs includes Truchyardiumangulatumand Fragumunedo, whereas 
mangrove molluscs includes Telescopiumtelescopium, Telebraliapalustfis, Ellobium aurisjudae, Syncerabrevicula, Chicoreous adustus, Polymesoda Scylla senatacoaxans and Anadara antiguata, as well as several crab species. Beside those two invertebrates, there was also another remnant of marine animal ecotone that is hawksbill turtle (Eretmochelysimbricata).

Vertebrate animals were determined as mammalians such as boars (Sus celebensis), deer (Cervustimorensis), big rats (Rattus rattus), Sulawesi weasel (Macrogalidiamuschenbroela) and bats (Pteropus). There were also reptilian such as hawksbill turtle and lizard (Varanussalvator). Based on the determination, we could trace the hunting strategies for marine, mangrove and terrestrial animals hunting.

The strategy for marine animal hunt was inferred from analysis on marine molluscs Truchyardiumangulatum and Fragumunedo. In accordance with analysis on their ecological component, it was found that these two molluscs lives in an opened marine environmental with a distance of about one mile from coastline and average depth of 10-45 m by Ansarullah and Rais. From their ecotone, shells catchment must have been conducted using transportation tools such as boat. Based on the discovery of turtle shells (Eretmochelysimbricata) at Leang Pamekalang Tedong (a cave which located within the prehistoric caves region of Labbakkang, Pangkep), it was found that in addition to marine molluscs, people also hunt sea turtles. On the other hand, albeit archaeological data are not found yet, peoples who lived at Belae caves complex were assumed to have hunted big fishes in open seas. The tools used in the hunt must be transportation and weapon tools.
The strategies for mangrove fauna hunting could be explained by classifying mangrove animals into fixed and temporary mangrove animals. The first is includes mangrove molluscs and crabs. Consumed mangrove molluscs by peoples who lived at Belae caves were Telescopiumtelescopium, Telebraliapajusttis, Ellobiumautisjudae, Nelitaplanospira, Chicoriusadusrts, Polymesodacoaxans and Anadara antiguata. For the crabs, there was Scylla serrata or mud crab. Temporary mangrove animals which consumed are reptilians such as lizard (Varanussalvator) and bats (Pteropus). There was also a possibility that others temporary animals such as monkeys (Macacafasciculatoris) and boars were consumed as their bones were found at several caves at Belae, Pangkep.

The way of mangrove animals hunt, particularly those of mollusc species is assumed to being conducted using sampan, since, those species were lived in area which always flooded by sea water and thus sampan must be used. Other molluscs were hunted during the recede of sea water when the salinity of sea water is low. The way of catching mud crab was at night as the crabs search for food in that time. In such conditions, the crabs were hunted by using nets or traps by Suprapta.

Beside adapted to aquatic environment, in their effort to get the food, it seems that peoples who occupied Belae caves were also hunt terrestrial animals, particularly those of vertebrate such as boar (Sus celebensis) and deer (Cervustimorensis) as well as rats (Rattus rattus), Sulawesi weasel (Makrogalidiamuschenbroela) and jungle fowl (Gallus galvus). This occurred because it seems that naturally subsistence activities in land are much easier than in water area (Fig. 4).

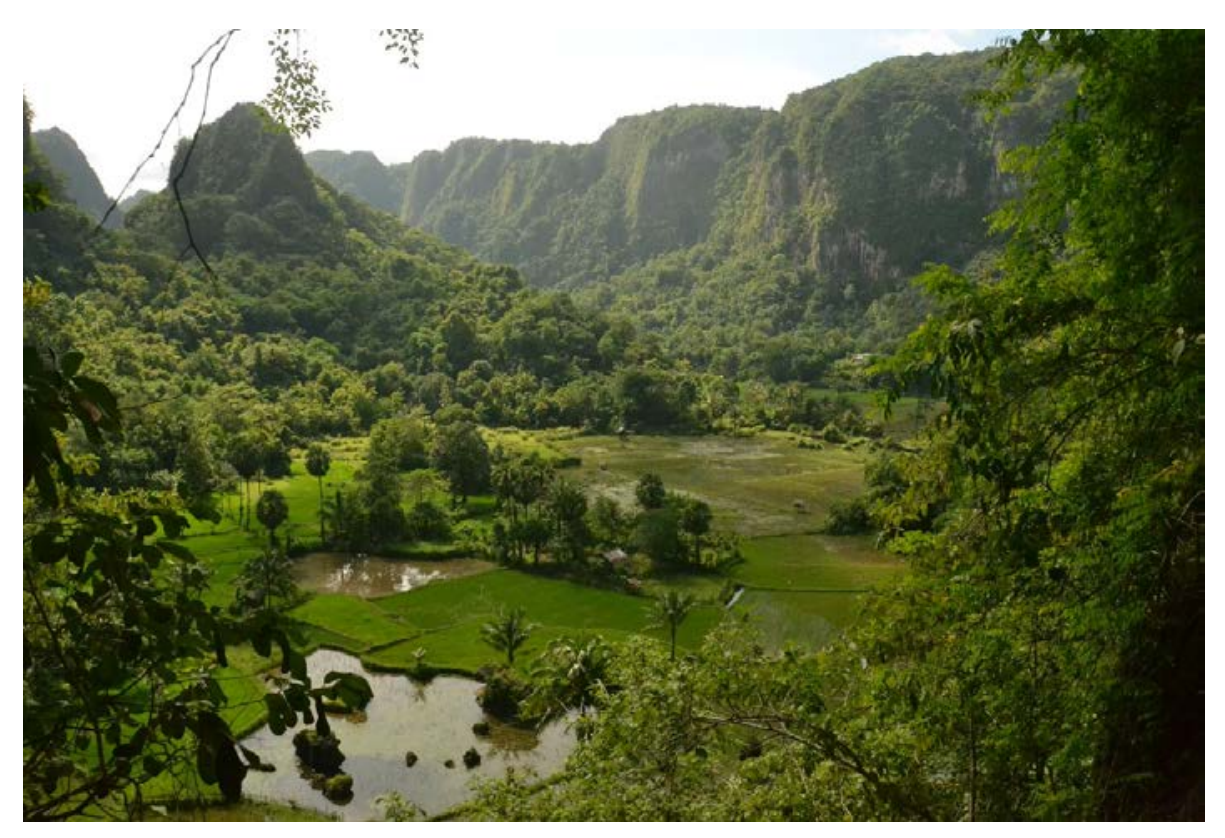

Fig. 4: Situations of prehistoric caves at Belae village 


\section{CONCLUSION}

The selection of caves as a settlement in Mesolithic times was highly influenced by environmental factor. In fact, past environments were varied according to the nature of its ecosystems which forced human to choose their environmental adaptations. Human capability to choose favorable environment was based on strategic considerations such as harmonic distance from food sources, secure for shelter and so on. In prehistoric times, particularly the Mesolithic, human has been able to choose their adaptation environment which strategically could provide their needs which led to the development of more advanced culture rather than before.

By investigating artefacts and non-artefacts evidence which collected from Belae village prehistoric cave region, we could identify environmental situation and conditions which favorable for human life in that era. The description of environment above is important examples which demonstrate the position and roles of environment in support human life at prehistoric time.

\section{REFERENCES}

Aubert, M., A. Brumm, M. Ramli, T. Sutikna, E.W. Saptomo, B. Hakim and A. Dosseto, 2014. Pleistocene cave art from Sulawesi, Indonesia. Nature, 514: 223-227.
Duli, A. and Rosmawati, 2018. Late prehistoric burial system in South Sulawesi. ELS. J. Interdiscip. Stud. Humanities, 1: 134-144.

Duli, A., 2013. The mandu coffin: A boat symbol of ancestral spirits among the Enrekang people of South Sulawesi. Rev. Indonesian Malaysian Affairs, 47: 115-138.

Duli, A., 2014. Shape and chronology of wooden coffins in Mamasa, West Sulawesi, Indonesia. Int. J. Hist. Stud., 5: 177-186.

Duli, A., 2015. Typology and chronology of Erong wooden coffins in Tana Toraja, South Celebes. J. Archaeol. Consciousness Culture, 8: 3-20.

Glover, I., 1976. Ulu leang cave, maros: A preliminary sequence of post-Pleistocene cultural development in South Sulawesi. Archipel, 11: 113-154.

Ismail, N.N.A., Z. Ramli, N.S.M. Supian, A. Hussin and A. Duli, 2018. Hoabinhian's lithic technology in chawan cave, hulu Kelantan. Int. J. Mech. Eng. Technol., 9: 1007-1016.

Roslan, Z., Z. Ramli, C. Shin, E.A. Choy and M.R. Razman, 2017. Local community perception on the importance of cultural-natural heritage protection and conservation: Case study in Jugra, Kuala Langat, Selangor, Malaysia. J. Food Agric. Environ., 15: 107-110.

Supian, N.S.M., Z. Ramli, N.N.A. Ismail, A. Hussin and A. Duli, 2018. The study of earthenware at Jaya cave prehistoric site, Hulu Kelantan. Int. J. Mech. Eng. Technol., 9: 998-1006. 